have had only some 350 places available in all. This number is now being increased by more than 60 per cent, and substantially higher grants are to be paid to students, in order to attract the right quality and quantity of candidates from those already settled in industry and commerce. Candidates are accepted as either 'private' or 'recognized' students for a course of one academic year. The latter pay no tuition fees, are offered free board and lodging in the college hostels and are eligible for maintenance allowances. To be accepted a candidate should normally have reached his twenty-fifth birthday, should possess a degree, Higher National Certificate or equivalent qualification and should have some commercial or industrial experience. Further information can be obtained from the Director, Huddersfield Training College, Queen Street South, Huddersfield.

\section{Royal Society Expedition to Southern Chile}

THe Royal Society has announced that plans are being made, in co-operation with the Royal Society of New Zealand, to send a small expedition to southern Chile in September. Dr. Martin Holdgate, Zoology Department, University of Durham, has been appointed organizer, and Mr. G. A. Knox, Canterbury University College, New Zealand, and Dr. E. J. Godley, director of the Botany Division of the New Zealand Department of Scientific and Industrial Research, will also take part. The University of Chile has expressed its interest and also hopes to send representatives. It is intended that this expedition should be exploratory and preliminary to a proposed Commonwealth expedition to the South Pacific area.

Many genera and species of animals and plants occur both in South America and in New Zealand and Tasmania. The precise extent of this relationship remains uncertain, however, although its elucidation is clearly important for an understanding of biological evolution and of the past history of the Earth's surface. The fauna and flora of the world are now changing so rapidly through man's activity that it is likely that within another generation precise information about the natural distribution of animals and plants will be unobtainable, so that further research is needed urgently. A great deal of work has been done on the biology of New Zealend and its neighbouring islands, but by comparison southern Chile has been little studied. The present expedition's first visit will therefore be to the western hills of the island of Chiloe, where there are extensive tracts of dense evergreen rain-forest, and it will then proceed southward towards the Straits of Magellan. Ecological and geological studies will be made in the three areas it is proposed to visit, and peat samples will be collected from mountain bogs and lowland lakes in connexion with pollen analyses, from which it is hoped to learn something about past climatic and vegetational changes in the region.

\section{Bardsey Observatory}

The report of Bardsey Bird and Field Observatory for 1956 (Eglwysfach, near Machynlleth, Mont.: W. M. Condry, Hon. Secretary, 1957) contains details of many successful observations and developments. In a year of unusually heavy migration twice as many birds were ringed as in any previous season; more than a thousand birds were ringed at the lighthouse at night. Among the more unusual birds recorded were the melodious warbler, Hippolais poly. glotta, and the greenish" warbler, Phylloscopus trochiloides. During the year a visit was paid by botanists from the University College of North Wales, who surveyed the island's flora and prepared a species list, which is included in the report. The Observatory is open to visitors, particularly during the months of May, June and July. Further information can be obtained from W. M. Condry, Eglwysfach, Near Machynlleth, Montgomeryshire.

University News :

London

THe following appointments have been made: Dr. C. P. Whittingham, assistant director of research in botany in the University of Cambridge, to the University chair of botany tenable at Queen Mary College; and Dr. A. R. Flint, consulting civil engineer, to the University readership in structural steelwork tenable at the Imperial College of Science and Technology.

\section{Announcements}

DR. G. A. H. Elton, at present reader in applied physical chemistry at Battersea College of Technology, has been appointed director of research of the British Baking Industries Research Association, Chorleywood. Dr. Elton's research has been mainly in the field of colloid chemistry. He was awarded the degrees of Ph.D. and D.Sc. of the University of London for work on this subject and for a number of papers which he has published in the field of rheology.

The Sixth Conference of the British Agricultural History Society will be held on April 10 and 11 at the Yorkshire (W.R.) Institute of Agriculture, Askham Bryan, York. Further information can be obtained from the Secretary of the Society at the Department of Agriculture, Parks Road, Oxford.

THE Scottish Group of the Nutrition Society is holding a symposium on "Nutrition and Climatic Stress" at the Hannah Dairy Research Institute, Kirkhill, Ayr, on April 26, when papers will be read on both human and animal nutrition. Further particulars may be obtained from Dr. J. Davidson, The Rowett Research Institute, Bucksburn, Aberdeenshire.

THE Scottish Branch of the Science Masters' Association is to hold its annual general meeting during April 10-12, in the University Chemistry Department, King's College, Aberdeen. The programme includes lectures, exhibitions and visits to places of scientific interest. Further information can be obtained from D. W. Menzies, Aberdeen Acedemy.

THE Ergonomics Research Society is holding a conference on "Problems of Training" at the University of Bristol during April 13-16. Further information can be obtained from Dr. O. G. Edholm, Department of Human Physiology, M.R.C. Laboratories, Holly Hill, Hampstead, London, N.W.3.

THe Operational Research Society is to hold an open conference at the Old Swan Hotel, Harrogate, during May 21-22. The conference will afford to representatives of commerce and industry an opportunity to discuss current applications of operational research. The main theme of the conference is "Aids to Decision Making". Further information can be obtained from the Honorary Secretary of the Operational Research Society, 3rd Floor, 20 Albert Embankment, London, S.E.11. 